\title{
OS DESAFIOS DA RECEPÇÃO DOS REFUGIADOS NO BRASIL NA ERA DA INFORMAÇÃO: O PARADIGMA DA INFORMAÇÃO NO PROCESSO DE INSERÇÃO SOCIAL E NA (DES)CONSTRUÇÃO DOS DISCURSOS XENOFÓBICOS
}

THE CHALLENGES OF THE RECEPTION OF REFUGEES IN BRAZIL

IN THE INFORMATION AGE: THE INFORMATION PARADIGM IN THE SOCIAL INSERT PROCESS AND THE CONSTRUCTION OF XENOPHOBIC DISCOURSES

\section{JUCEMAR DA SILVA MORAIS ${ }^{1}$ LETÍCIA CAROLINA FERREIRA ${ }^{2}$ JÚLIA GARCIA DA SILVA ${ }^{3}$}

ISSUE DOI: $10.21207 / 1983.4225 .525$

\section{RESUMO}

O presente artigo propõe uma reflexão crítica sobre o processo de integração dos refugiados no Brasil e os reflexos e desafios que esse

\footnotetext{
${ }^{1}$ Doutorando na Faculdade Autônoma de Direito. Mestre em Direito pela Unesp. Professor na Libertas Faculdades Integradas de São Sebastião do Paraíso e Fafram - Ituverava/SP. Professor convidado na Faculdade de Direito de Franca/SP. Advogado.

${ }^{2}$ Graduanda do $6 .^{\circ}$ Período no curso de Direito da Faculdade Francisco Maeda (Fafram) em Ituverava/SP. Estagiária no escritório Moisés, Volpe e Del Bianco.

${ }^{3}$ Graduanda do 6. ${ }^{\circ}$ Período no curso de Direito da Faculdade Francisco Maeda (Fafram) em Ituverava/SP. Estagiária no escritório Moisés, Volpe e Del Bianco.
} 
objetivo obtêm a partir de sua inserção em um contexto de franco desenvolvimento da chamada Era da Informação. Para tanto, inicia-se com a discussão em torno do atual cenário formado a partir do desenvolvimento das tecnologias da informação e o impacto que esse fenômeno causa num mundo globalizado. Considerando que, dentre os desafios para a compreensão do fenômeno da imigração, está inserido, como parte do problema, inclusive, o debate conceitual acerca das distintas formas de compreendêlo, nesse enfoque inicial procurar-se-á pontuar como o uso dessas tecnologias, da mídia às redes sociais, exerce forte influência quanto à acolhida ou rejeição dos refugiados, considerando-se os meios pelos quais o diálogo e o debate são conduzidos a partir do uso desses mecanismos. Ressalte-se, nesse processo, a identificação de uma tendência de se fazer prevalecer um discurso discriminatório e xenofóbico com relação a essas questões (daí porque se disse que tal debate faz parte do problema como um todo) e, por essa razão, ao final, lançam-se reflexões em torno desse processo, sobretudo quanto aos desafios relacionados ao desenvolvimento de uma perspectiva solidária e cooperativa de acolhimento e garantia de direitos dos povos refugiados.

Palavras-chave: Discursos discriminatórios; Refugiados; Sociedade da Informação; Xenofobia; Solidariedade.

\section{ABSTRACT}

This essay proposes a critiical reflection on the process of integration of refugees in Brazil and the reflexes and challenges that this objective obtains from its insertion in a context of frank development of the so-called Information Age. To do so, it begins with the discussion around the current scenario formed from the development of information technologies and the impact that this phenomenon causes in a globalized world. Considering that, as part of the problem, including the conceptual debate about the different ways of understanding it, one of the challenges to understanding the phenomenon of immigration is inserted, in this initial approach we will try to point out how the use of these technologies, From the media to social networks, exerts a strong influence on the acceptance or rejection of refugees, considering the means by which dialogue and debate are conducted through the use of these mechanisms. In this process, the identification of a tendency to make discriminatory and xenophobic dis- 
course prevail in relation to these issues (hence it was said that such a debate is part of the problem as a whole) and, for that reason, at the end , There are some reflections on this process, especially regarding the challenges related to the development of a solidarity and cooperative perspective of reception and guarantee of the rights of refugee peoples.

Key words: Discriminatory speeches; Refugees; Information Society; Xenophobia; Solidarity

\section{INTRODUÇÃO}

A ordem que agora comanda o cenário mundial impõe a construção do conhecimento por vias da informação que se difunde em uma proporção jamais vista em qualquer outro momento da história da humanidade.

Com o avanço e o desenvolvimento tecnológico, sobretudo a partir da década de 70, com a consequente expansão e modernização dos meios técnico-científicos, oportunizou-se o surgimento de novos paradigmas no âmbito da comunicação, culminando na formação de uma nova sociedade que ficou conhecida por Sociedade da Informação.

O mundo globalizado, então marcado pelos avanços tecnológicos, especificamente na seara das comunicações, tem revelado o papel das tecnologias de informação e comunicação (TIC ${ }^{4}$ ) como instrumentos eficazes no processo de desenvolvimento humano e social e, não obstante, têm suscitado, de modo pertinente, os debates relacionados ao exercí-

\footnotetext{
${ }^{4}$ Marcelo Thompson demonstra muito bem o cenário em que nos situamos: "Em seu livro Tecnopolitica, Stefano Rodotà argumenta que as novas tecnologias de comunicação proporcionam o surgimento de uma democracia contínua no tempo e no espaço. Nessa democracia, segundo Rodotà, o acesso às novas tecnologias promove a distribuição de poder de uma forma que, diversamente do que pregavam modelos teóricos anteriores, não acarreta a fragmentação política e social. Ao contrário, a redistribuição de poder promovida pelas novas tecnologias enseja uma conexão entre os diferentes sujeitos políticos e, com isso, possibilita um permanente reequilíbrio no qual repousa uma nova forma de estabilidade política - e uma diante da qual modalidades de autoritarismo perdem sua eficiência". Cf. em THOMPSON, Marcelo. Marco civil ou demarcação de direitos? Democracia, razoabilidade e as fendas na internet do Brasil. RDA - Revista de Direito Administrativo, Rio de Janeiro, v. 261, p. 203-251, set./dez. 2012. Disponível em: <http://ssrn.com/abstract=2101322>. Acesso em: 08 jun. 2014.
} 
cio dos direitos de cidadania, em que pese, notadamente, a liberdade de informação e de expressão e do pertinaz embate sobre a dignidade da pessoa humana.

Isto porque, malgrado serem indiscutíveis a eficiência e relevância dos meios tecnológicos para a sociedade contemporânea (e, de certa forma, para as gerações futuras que certamente usufruirão de avanços ainda melhores), essa nova sociedade requereu a utilização da tecnologia, sobretudo da informação, como ferramenta fulcral nas relações sociais, políticas, econômicas e culturais, sobrepondo-a ao ser humano na mesma proporção em que estão sendo rebaixados os valores sociais, os padrões éticos e os próprios direitos fundamentais.

Com efeito, essas transformações alastraram-se por toda a malha social, e o advento das novas tecnologias trouxe a lume a necessidade de propiciar novas relações, sobretudo entre os indivíduos, justamente como meio de adaptar a sociedade aos novos moldes, agregando novos valores sem, contudo, modificar a sua essência. Todavia, de outra ponta, não só o fluxo informacional e tecnológico se elevou. Simultaneamente à evolução tecnológica, mormente no que se refere ao aspecto informacional, o mesmo ocorreu com os fluxos migratórios que passaram a se elevar em grandes proporções.

Deve-se considerar que, desde os primórdios da humanidade, têm-se observado as grandes e constantes movimentações vivenciadas pelos mais variados povos, seja na busca por melhores condições de sobrevivência, seja porque as circunstâncias assim determinaram. A existência de novos espaços e de novas oportunidades atraiu e possibilitou a movimentação de diversos grupos que passaram a se deslocar de um território para outro, fenômeno esse que ficou conhecido como "migração".

$\mathrm{O}$ direito de migrar existe simplesmente porque a busca pela felicidade é inerente ao ser humano. Todavia, a felicidade - entendida como uma oportunidade de trabalho, a formação de uma família, a satisfação pessoal, etc. - nem sempre figura como protagonista da migração. Em várias passagens da história humana é possível identificar o deslocamento de alguns grupos para outros lugares que se deram não de forma voluntária, mas forçada, porque as circunstâncias - alheias às suas vontades assim determinaram. 
A migração forçada ${ }^{5}$ se dá, demasiadas vezes, como consequência de perseguições motivadas por questões políticas, sociais, econômicas, raciais, culturais, étnicas e por conflitos armados. O medo, oportunizado pela violência, constitui o cerne das migrações forçadas e fomenta o pesadelo da comunidade que nos últimos tempos mais tem sofrido as consequências: os refugiados.

Nesse sentido, foi no século XX que se revelou um dos maiores e mais complexos desafios no tocante às causas humanitárias, muito em razão da nova dinâmica estrutural da sociedade da informação e dos fenômenos dela advindos. O segundo pós-guerra trouxe a lume a questão dos refugiados, colocando o mundo diante de uma crise migratória de grande e complexa proporção, que redesenhou o mapa global e introduziu uma nova percepção acerca da proteção dos direitos humanos ${ }^{6}$.

Os refugiados são pessoas compelidas a migrar em decorrência de causas antrópicas, observadas através das perseguições por motivos que refletem suas características pessoais, físicas e posicionamentos culturais, políticos e religiosos, bem como por meio da grave e generalizada violação de seus direitos, sendo que esta tormentosa questão é objeto de proteção e amparo dos sistemas internacionais estabelecidos no âmbito da Declaração Universal dos Direitos Humanos ${ }^{7}$. Todavia, essa situação

5 A migração forçada, para Fatazzini, "se caracteriza pela necessidade que se impõe a indivíduos ou a grupos inteiros de deixar o local ou país de origem por causas alheias à sua vontade. Essas causas podem ser de origem econômica, social, desastre natural, desastre econômico e outros fatores relevantes que provoquem crises humanitárias. Ou seja, situações onde o sistema de organização social não pode garantir as necessidades indispensáveis de sobrevivência, ao todo ou parte da população". FANTAZZINI, Orlando. Uma agenda proativa para as migrações internacionais. In: ACNUR. Políticas Públicas para as migrações internacionais: migrantes e refugiados. Brasília: Alliance Indústria Gráfica, 2005, p. 11-12.

${ }^{6} \mathrm{O}$ número de refugiados decorrentes da Segunda Guerra Mundial é um tanto controverso e pode variar a depender da fonte consultada. De acordo com Eric Hobsbawm, a II Guerra implicou no surgimento de 40,5 milhões de refugiados, enquanto a Primeira Guerra totalizou entre 4 e 5 milhões, a descolonização da Índia 15 milhões e a Guerra da Coréia provocou o deslocamento interno de 5 milhões de pessoas. Ver: HOBSBAWM, Eric. Era dos extremos: o breve século XX (1914-1991). 2. ed. Tradução: Marcos Santarrita. São Paulo: Companhia das Letras, 1995, p.57-58.

${ }^{7}$ A Declaração Universal dos Direitos Humanos (DUDH) é um instrumento internacional considerado o marco histórico no que se refere aos direitos humanos, visto que estabeleceu, pela primeira vez, a proteção universal dos referidos 
atípica e de extrema vulnerabilidade não se encerra quando o refugiado migra forçosamente de seu país de origem, mas se prolonga quando da sua chegada ao país acolhedor. Isto porque, imerso nas perdas, traumas e violências da travessia, busca se socorrer em um local desconhecido, de cultura e idioma distintos, em uma sociedade que por vezes se apresenta ignorante, preconceituosa e receosa com sua chegada. Essa postura tem despertado a ascensão de grupos ultranacionalistas, incentivadores de práticas discriminatórias, xenofóbicas e de discursos de ódio contra os refugiados, principalmente na Europa.

Apesar de velada, ainda existe por parte da sociedade uma discriminação quanto à sua presença e certo desprezo generalizado à sua figura, muito em razão dos fenômenos construídos pela sociedade da informação.

Dá-se, então, o presente artigo, ao propósito de debater o paradigma da informação no processo de inserção social e de (des)construção dos discursos xenofóbicos, especificamente no que respeita à recepção dos refugiados no Brasil. Tendo-se em vista as interfaces da informação e os fenômenos dela advindos, especialmente no que se refere à propagação de conteúdos que revelam discursos discriminatórios e violadores de direitos, emerge a necessidade de se analisar e utilizar a informação em seu viés positivo, como uma ferramenta reconstrutora de direitos fundamentais e não construtora e precursora de discursos de ódio. Uma ferramenta que cumpra seu mister e reafirme a essência do Direito à Informação, levando às pessoas o acesso a conteúdos que viabilizem a troca de saberes, o exercício da liberdade de expressão dentro de seus limites, o respeito recíproco e a promoção dos direitos humanos.

De forma a cumprir esse propósito, a pesquisa utilizou-se do método monográfico, através da análise documental e bibliográfica com base em materiais publicados em livros, revistas, artigos e redes eletrônicas, valendo-se, inclusive, de situações fáticas (casos emblemáticos) vivenciadas pelos refugiados na sociedade brasileira. Buscou-se, pois, analisar a informação em seu aspecto positivo e negativo, isto é, enquanto

direitos. Foi proclamada pela Assembleia Geral das Nações Unidas, na cidade de Paris, em 10 de Dezembro de 1948, por intermédio da Resolução 217 A (III). Nos termos do que dispõe seu art. 14, inciso I, in verbis: "Todo ser humano, vítima de perseguição, tem o direito de procurar e de gozar de asilo em outros países”. 
ferramenta de construção e de desconstrução dos discursos xenofóbicos e a sua influência no processo de acolhimento dos refugiados no Brasil.

A sociedade brasileira ainda caminha a passos miúdos em comparação com a velocidade com a qual avança a sociedade da informação. Por esta razão, diante de uma crise humanitária de tamanhas proporções, o que se espera de uma sociedade, cuja formação remonta à junção de diversas etnias, é mais do que acolher os refugiados; é reconhecer nessas pessoas a própria origem do povo brasileiro, atribuindo à informação uma função de verdadeira ferramenta difusora dessa ideia.

\section{1

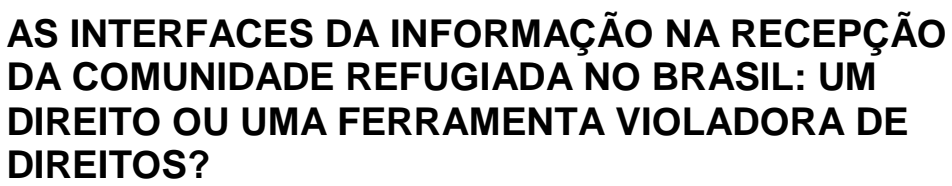

A nova ordem informacional e a dinamicidade de suas tecnologias pressupõem, para a eficácia de seus instrumentos, um respeito mútuo no que asseveram os direitos fundamentais.

Isto porque a difusão da informação, em seus mais diversos meios de propagação, nada mais é senão o exercício dos direitos de cidadania, entre os quais o de informar e ser informado. E, por esta razão, requer um cuidado em seu manuseio porque, embora seja um direito, é também um instrumento por muitos utilizado para a violação de demais direitos, principalmente diante de uma sociedade absurdamente conectada e que de tempos em tempos viola as garantias de uns em nome da liberdade de expressão de outros.

A mídia, através de seus diversos meios de propagação (as chamadas tecnologias da informação e comunicação - TIC), divulgou assídua e freneticamente a crise dos refugiados, dando margem ao surgimento de dúvidas pela sociedade a respeito da crise e, especificamente, sobre "quem são os refugiados". Isto porque parte da sociedade não conhecia referido termo, seja porque este possui raízes na ciência jurídica ${ }^{8} \mathrm{e}$

${ }^{8}$ O conceito de refugiado encontra sua definição na Convenção Relativa ao Estatuto do Refugiado, de 1951, parcialmente alterada por seu Protocolo Relativo de 1967. De acordo com esses documentos, pode-se considerar refugiada a pessoa "que temendo ser perseguida por motivos de raça, religião, nacionalidade, grupo social ou opiniões políticas, se encontra fora do país de sua nacionalidade 
poucos a conhecem, seja em razão da ausência de interesse pelo tema, ou mesmo face às poucas notícias a estes vinculadas, até então.

Todavia, as informações repassadas sobre o conceito e a condição de refugiado nem sempre encontram amparo técnico ou legal e, não raro, são acompanhadas de pré-conceitos carregados de ódio, intolerância e discriminação. Isto porque a era da informação, em razão de todos os avanços da sociedade moderna e dos interesses particulares que tocam ao ser humano, tem construído relações interpessoais e sociais que se sobrepuseram aos direitos fundamentais, tornando-se verdadeiras ferramentas difusoras de discursos preconceituosos e violadores de direitos, revelando uma interface discriminatória de um direito que deveria ser exercido para promover e incentivar o respeito mútuo e a valorização da pessoa no que toca a sua intrínseca qualidade de ser humano. Como esse ideal não tem prevalecido, o que se observa é que muitos têm se valido desse exercício fundamental e consagrado para atingir a dignidade humana em nome da chamada "liberdade de expressão"".

É nessa senda, pois, que insurge o paradigma da informação: ser uma via de mão dupla. Se por um lado a informação, direito constitucionalmente assegurado ${ }^{10}$ que a todos se estende, é uma importante e valiosa ferramenta na obtenção e troca de saberes, no exercício da liberdade de

e que não pode ou, em virtude desse temor não quer valer-se da proteção desse país, ou que, se não tem nacionalidade e se encontra fora do país no qual tinha sua residência habitual, não pode ou, devido ao referido temor, não quer voltar a ele".

${ }^{9}$ Não devemos confundir o chamado discurso de ódio (hate speech) com a consagrada e fundamental liberdade de expressão. Para Waldron, objetivo pretendido por aquele que faz uso desse tipo de discurso, sobretudo quando proferido nas redes sociais (onde a propagação da informação atinge escala mundial e indeterminada) é humilhar e, não raras vezes, despertar o medo e o terror nas pessoas ou grupos sociais (no mais das vezes, vulneráveis ou minoritários) evidenciando que, por suas características específicas, eles não são dignos da mesma participação política. A intenção daquele que se manifesta por meio do ódio é fazer calar, excluir e alijar, da forma mais torpe possível, o alvo de sua verborragia. WALDRON, Jeremy. Dignity and defamation: the visibility of hate. Harvard Law Review, v. 123, n. 1.596, p. 1.597-1.657, 2010.

${ }^{10}$ Dispõe o caput do art. 220 da Constituição da República que: "A manifestação do pensamento, a criação, a expressão e a informação, sob qualquer forma, processo ou veículo não sofrerão qualquer restrição, observado o disposto nesta Constituição" (grifo nosso). BRASIL. Constituição Federal da República Federativa do Brasil de 1988. Disponível em www.planalto.gov.br/constituição Acesso em 21/05/2017. 
expressão ${ }^{11}$ e na consecução das relações sociais, é, de forma oposta, um ambiente que possibilita os mais diversos discursos e manifestações de pensamentos que, não raro, extrapolam os seus limites, atingindo os direitos fundamentais do ser humano, rompendo com a verdadeira essência da informação, qual seja, o direito de informar, se informar e ser informado de conteúdos verdadeiros e que não deturpem a dignidade do ser humano e seus demais direitos, mas que viabilizem a troca de culturas, de conhecimentos e de incentivo ao respeito recíproco como condição para um convívio em sociedade de forma harmônica e sadia.

\subsection{A ERA DA INFORMAÇÃO E OS DISCURSOS NA ERA DO ÓDIO}

A propagação da informação tem sido pilar fundamental na formação da opinião pública. Ocorre que essa propagação contribuiu também para a ascensão e fomento de inúmeros discursos preconceituosos e incentivadores de práticas odiosas e xenofóbicas, em especial no que respeita à comunidade dos refugiados, objeto do presente estudo.

É nesse contexto que a recepção dos refugiados em terras brasileiras encontra uma série de desafios. A informação, em seu viés totalitário e de patente violação dos direitos humanos e fundamentais, tende a criar obstáculos no processo de acolhimento, inserção e integração social. Não obstante ser a sociedade da informação um espaço para o exercício do direito à informação e da liberdade de expressão, há que se ressaltar o ambiente de risco que referida sociedade constrói.

São especificamente estes riscos que obstam a aceitação dos refugiados na sociedade brasileira porque permitem a sua estigmatização,

\footnotetext{
${ }^{11}$ Nos dizeres de J. J. Gomes Canotilho, a liberdade de expressão, tal como consagrada na Constituição da República, teria a imprescindível e fundamental função de garantir aos cidadãos o que se denomina de status negativo, ou seja, a não intervenção prévia do Estado em suas manifestações. Isso, todavia, não quer dizer que a liberdade de expressão, embora fundamental, não é um direito de dimensões ilimitadas como não o é nenhum outro direito. Nesse sentido, segundo Mendes, "a proibição de censura não obsta, porém, a que o indivíduo assuma as conseqüências, não só cíveis, como igualmente penais, do que expressou". Cf., nesse sentido, MENDES, Gilmar Ferreira; COELHO, Inocêncio Mártires; BRANCO, Paulo Gustavo Gonet. Curso de Direito Constitucional. São Paulo: Saraiva, 2009, p. 404.
} 
condicionando-os a certos estereótipos e padrões de comportamento que, não observados, acarretam a sua não aceitação pela sociedade.

Esses estereótipos e padrões considerados "normais" pela sociedade, geral e constantemente criados e veiculados pelos mais diversos meios de comunicação (internet, televisão, rádios, etc.), ditam como o homem deve ser, agir e pensar para ser aceito na respectiva sociedade. Sendo a maioria da população leiga, desprovida muitas vezes dos conhecimentos básicos, a manipulação logra êxito e aqueles padrões são facilmente incorporados pelas pessoas, criando uma barreira quase que intransponível para a aceitação e a convivência com uma nova cultura ou com os novos costumes que são trazidos na bagagem de um refugiado. Com isso, há o rompimento ou mesmo a destruição da empatia gerando, assim, dificuldades ainda maiores para oportunidades de crescimento e desenvolvimento do país, seja no aspecto cultural, social ou mesmo econômico, pois há a disseminação dessa infeliz e distorcida ideia de que aquele que veio de fora é quem precisa se adaptar, e não o contrário.

Nessa linha aponta Erving Goffman, considerado como um dos "pais da Sociologia", em sua obra, Estigma: la identidade deteriorada, que "la sociedad establece los medios para caracterizar a las personas y el complemento de atributos, que se perciben como corrientes y naturales a los miembros de cada uma de esas categorías"12 e é isso o que causa, nesses indivíduos, uma visão distorcida e que deve ser evitada como qualquer outro mal. Segundo o sociólogo, a sociedade cria um modelo e tende a classificar as pessoas de acordo com os seus atributos e são essas características que determinam a qual grupo pertencerá essas pessoas. Nesse sentido, a sociedade estabelece um padrão social que passa a ser tido como normal, e aquele que a ele não se adapta ou que apresenta atributos diferentes dos demais tende a ser pouco aceito ou totalmente reprovado.

Essa estigmatização, caracterizada pela intensa desaprovação das características pessoais de uma pessoa ou de determinado grupo, face à difusão frenética de padrões e estereótipos, transforma o sonho de um refugiado em pesadelo quando este chega ao país ao qual pretende solici-

${ }^{12}$ GOFFMAN, Erving. Estigma: la identidad deteriorada. 5. ed. Buenos Aires: Amorrortu Editores, 1993, 172p. In: Zélia Maria de Melo. Os estigmas: a deterioração da identidade social. Disponível para consulta online em: <http://proex.pucminas.br/sociedadeinclusiva/anaispdf/estigmas.pdf〉. Acesso em: 30 mai. 2016. 
tar refúgio. A sociedade contaminada pelas informações transmitidas erroneamente e compartilhadas na velocidade da luz impõe restrições no acolhimento dos refugiados.

Esse pensamento retilíneo, uniforme, inflexível e, de certa forma, rígido encontra sua guarida quando a informação passa a ser distorcida e utilizada como um meio manipulador e precursor dos modelos sociais pré-definidos pela sociedade, tidos como obrigatórios. Essa manipulação ocorre facilmente quando o receptor de determinada informação acredita naquilo que vê, lê e ouve sem discutir o seu porquê. A razão disso é que o acesso seco à informação em seus diversos meios não é suficiente para a compreensão da realidade tal como é. A assimilação da informação requer, para a sua transformação em verdadeiro conhecimento, um interesse maior na compreensão do fato em sua realidade, que pressupõe uma observação e leitura crítica sobre aquilo que é passado.

Significa dizer que a informação, quando absorvida pela "primeira impressão", não é suficiente, pois é justamente essa primeira impressão que leva o indivíduo a uma visão equivocada sobre os refugiados. É preciso fazer uma análise, uma interpretação, uma discussão acerca daquela informação, não sendo exigível, nesse sentido, um conhecimento estritamente aprofundado sobre o tema. $\mathrm{Na}$ era da informação é necessário ter interesse em adquirir o conhecimento.

Nesse cenário oportuno se faz a menção de uma frase cuja autoria é atribuída a Graça Caldas: "Sei tudo e não compreendo nada"13. As pessoas podem se informar, informar terceiros ou por eles serem informadas. Não obstante, a nova estruturação da sociedade da informação, com o seu dinamismo, pressupõe que os indivíduos se posicionem de sorte a compreender e refletir sobre aquilo que é transmitido para, inclusive, quebrar padrões e coibir estigmas.

Essa constante necessidade de compreender e refletir sobre a informação repassada se dá em razão da "natureza ideológica da linguagem" (Caldas, 2006). Graça Caldas, ao discorrer sobre o papel da mídia nas escolas, ensina que a linguagem midiática admite diversas interpreta-

${ }^{13}$ CALDAS, Graça. Mídia, escola e leitura crítica do mundo. Educ. Soc. Campinas, vol. 27, n. 94, p.117-130, jan./abr. 2006. Disponível em <http://www.scielo.br/pdf/es/v27n94/a06v27n94.pdf >. Acesso em: 01 Jul 2016. 
ções, e por esta razão se caracteriza como sendo ideológica. Santaella ${ }^{14}$, citado pela autora, assevera:

Toda linguagem é ideológica porque, ao refletir a realidade, ela necessariamente a refrata. Há sempre, queira-se ou não, uma transfiguração, uma obliqüidade da linguagem em relação àquilo a que ela se refere. Por sua própria natureza, de mediadora entre nós e o mundo, a linguagem apresenta sempre, inelutavelmente, um descompasso em relação à realidade. Ela não é, nem pode ser a realidade. A essa diferença substantiva entre a linguagem e o real acrescentam-se as diferenças adjetivas, quer dizer, as variações próprias às posições históricas e sociais dos agentes que a produzem e consomem. (Santaella, 1996, p. 330-331 apud Graça Caldas, 2006, p.122)

Significa dizer que a informação tende a ser repassada de maneira a atender os interesses daquele que a transmite, de sorte a manipular os receptores ou levando-os para uma interpretação equivocada e distante da realidade. A divulgação de informações distorcidas, especialmente no que respeita às grandes redes sociais (Facebook, Twitter, WhatsApp, etc.), tem ultrapassado os limites do tolerável. As poucas vezes que imigrantes e refugiados aparecem nos noticiários de TV ou nas redes de comunicação estão sempre atreladas a uma crise, a um problema, a marginalizações e crimes. Raras são as vezes em que destacam as contribuições culturais e as riquezas naturais dessas pessoas.

\section{UM MENINO À BEIRA-MAR: É POSSÍVEL FALAR EM SOLIDARIEDADE NA ERA DA INFORMAÇÃO?}

\footnotetext{
14 SANTAELlA, L. Produção de linguagem e ideologia. São Paulo: Cortez, 1996. In: CALDAS, Graça. Mídia, escola e leitura crítica do mundo. Educ. Soc. Campinas, vol. 27, n. 94, p.117-130, jan./abr. 2006. Disponível em <http://www.scielo.br/pdf/es/v27n94/a06v27n94.pdf >. Acesso em: 04 Jul 2016.
} 
É numa perspectiva solidária e humanitária que a sociedade da informação deve tratar os refugiados. Podemos afirmar isso como uma possibilidade, diante da perspectiva que até aqui consideramos?

E é justamente aqui que paira a crítica pretendida, acima, por Caldas: a informação não pode ficar restrita ao que é "simplesmente jogado" pelos canais de comunicação, sob pena de impor à sociedade a visão única e padronizada a respeito de determinada coisa, sem que a isso possa ser oposta alguma objeção ${ }^{15}$. Por mais que a informação seja um mecanismo necessário, ela não pode ser utilizada como difusora de padrões, da forma como ainda é, pois do contrário sempre haverá minorias, e sempre haverá manifestações discriminatórias, o que não se pode admitir em um século na qual se apregoa a igualdade e a dignidade.

O papel da mídia, no que diz respeito à comunidade dos refugiados, tem se restringido à divulgação da crise, e ao constante debate acerca dos direitos humanos e dos interesses políticos e econômicos, numa perspectiva sempre negativa em torno da questão. Se a maioria das informações divulgadas a respeito dos refugiados não se prende a evidenciar as suas verdadeiras características e qualidades, dificilmente a sua aceitação pela sociedade será viabilizada, justamente porque é natural de qualquer ser humano rejeitar aquilo que não conhece ${ }^{16}$.

15 SANTAELLA, L. Produção de linguagem e ideologia. São Paulo: Cortez, 1996. In: CALDAS, Graça. Mídia, escola e leitura crítica do mundo. Educ. Soc. Campinas, vol. 27, n. 94, p.117-130, jan./abr. 2006. Disponível em <http://www.scielo.br/pdf/es/v27n94/a06v27n94.pdf >. Acesso em: 04 Jul 2016.

${ }^{16}$ Em notícia veiculada no dia 16 de maio do corrente ano, o estudante haitiano, Getho Mondesir, teve frustrados seus planos de passar o final de semana com seu filho de oito meses porque, quando se dirigia o ponto de ônibus, na cidade de Foz do Iguaçu, foi atacado por um grupo de agressores que estava sentado numa mesa de bar com ofensas e impropérios como "macaco, você só está aqui por causa da Dilma, mas agora você vai ter que voltar", o que foi seguido por uma série de golpes, inclusive utilizando-se de garrafas de cerveja e, com isso, colocando um fim em seus planos para aquele final de semana. Inexistindo qualquer outro motivo aparente, tudo indica que o que motivou o ataque foi única e tão somente o sentimento de ódio e xenofobia em razão de sua origem, o que ficou claro pela escolha das palavras e ofensas que o grupo, repetidas vezes, resolveu utilizar contra ele. Cf. a reportagem, na íntegra, em: $<\mathrm{http} / / /$ portaliguacu.com.br/noticias-gerais/grupo-ataca-estudante-haitiano-emfoz-do-iguacu-12644>. Acesso em 10/07/2016. 
E é justamente por esta razão que a informação não pode se restringir à uma análise superficial e acrítica, sob pena de vangloriar eternamente os padrões criados e veiculados.

Emerge, portanto, a necessidade de se analisar a informação em seu viés positivo. Destarte, no que toca o seu papel no cenário global, é inegável que os meios de comunicação, por outro lado, tiveram papel primordial para sensibilizar milhares de pessoas que ainda não haviam despertado sua consciência para a proporção da crise humanitária vivenciada na Europa, nem mesmo para as condições precárias e desumanas em que viviam, e ainda vivem, os refugiados.

A trágica história do menino sírio, Alan Kurdi, de apenas três anos, encontrado à beira da praia da região de Bodrum, tornou-se símbolo mundial da crise dos refugiados após terem sido divulgadas pela mídia, e demais canais de comunicação, imagens da penosa manhã de 02 de setembro de $2015^{17}$. Este episódio, representativo da situação de calamidade de milhares de refugiados que buscam incessantemente abrigo nos mais diversos países, foi o responsável por uma comoção social mundial.

A partir deste momento a crise vestiu uma "nova roupagem", agora sim com a perspectiva de que toda a sociedade estava envolta e era responsável pela grave crise humanitária, pois o "sentir" foi maior do que qualquer forma de preconceito com a tragédia. Oportunas, então, as palavras de Ignacio Ramonet: "Na guerra das imagens, uma fotografia ou uma cena filmada, ecoando à dimensão planetária, podem ser mais eficazes que um exército inteiro." 18

As tecnologias da informação foram não só primordiais para o acolhimento dos refugiados, mas também atuam constantemente na integração dos mesmos ao país acolhedor. Justamente sob a perspectiva dos problemas a serem encontrados pelo refugiado no país receptor, o cofundador da Unidade de Inovação do Unicef (Fundo das Nações Unidas para a Infância), o norte-americano Christopher Fabian, chegou à conclusão de

17 Cf. reportagem a respeito, disponível em: <http://www1.folha.uol.com.b r/mundo/2015/09/1677028-foto-de-menino-refugiado-morto-na-praia-atrai-atenc ao-para-crise.shtml>. Acesso em 05/07/2016.

${ }_{18}$ Nesse sentido, cf. artigo disponível em: <http://www4.fe.uc.pt/fontes/traba lhos/2007006.pdf >. Acesso em 11 jun. 2016. 
que "um dos grandes problemas enfrentados constantemente pelos refugiados são os processos de identificação em cada país a que eles chegam". ${ }^{19}$

Depois do impacto gerado por esta emblemática tragédia, com a conscientização de todos os problemas e dificuldades em torno do dilema dos refugiados, um dos recursos informacionais que veio auxiliar na problemática questão foi um aplicativo muito conhecido atualmente neste cenário da informação: o WhatsApp. Através desta ferramenta, propõe-se, segundo o diretor do Unicef, "que os números de telefone usados pelos refugiados para se cadastrar no WhatsApp sejam uma forma de identificálos, já que o aplicativo é utilizado por grande parte deles para entrar em contato com amigos e familiares nos países de origem" ${ }^{20}$. Estes, e entre outros, são exemplos concretos de que a informação se torna cada vez mais uma ferramenta para facilitação e propagação de ideais humanitários, tornando-se um mecanismo eficaz no atual cenário global para o acolhimento dos refugiados.

É por esta razão que o ponto nevrálgico e de persistência nesse trabalho impõe que a informação seja utilizada na "desconstrução" dos discursos discriminatórios e xenofóbicos. Há, para o bem-estar da sociedade, uma necessidade de "ver com bons olhos" os avanços tecnológicos no tocante aos meios informacionais. É preciso, acima de qualquer outro fundamento, não possibilitar espaços para a difusão das práticas discriminatórias. É muita pretensão eliminar as várias formas de manifestações preconceituosas, mas é um desejo e uma medida necessária para inserção e integração dos refugiados (e de qualquer outro estrangeiro) no país. A sociedade deve romper com esse discurso xenofóbico para possibilitar o convívio harmônico entre brasileiros e estrangeiros.

Eliminar o preconceito soa um tanto quanto utópico em uma sociedade em que considerável parcela de seus membros pode ser considerada, ainda, no tocante à questão que envolve os refugiados, um tanto quanto egoísta, ignorante e adepta a padrões exacerbadamente nacionalistas, erroneamente propagados e incentivados. Contudo, já dizia o grande poeta uruguaio Eduardo Galeano em seu Las Palabras Andantes sobre a utopia: Ela está lá no horizonte: aproximo-me dois passos, ela se afasta dois passos. Caminho dez passos e o horizonte corre dez passos mais

19 Cf., notícia na integra disponível em: <http://g1.globo.com/tecnol ogia/noticia/2016/07/unicef-quer-usar-o-whatsapp-para-identificar-

refugiados.html>. Acesso em 11 jun. 2016.

${ }^{20}$ Ibidem. 
além. Por mais que eu caminhe, nunca a alcançarei. Para que serve a utopia? Serve para isso: para andar. ${ }^{21}$ Portanto, é preciso caminhar. A sociedade não deve permanecer na inércia. Significa dizer que investir em políticas de combate aos discursos preconceituosos e de incentivo ao respeito recíproco é convidativo, e mais, é essencial.

\section{OS DESAFIOS PARA A CONSTRUÇÃO DE UMA SOCIEDADE GLOBAL SOLIDÁRIA E COOPERATIVA NA ERA DA INFORMAÇÃO}

Não se pode permitir que "lá fora" o Brasil seja conhecido como um país receptivo e acolhedor, quando em verdade a sociedade age ao revés. Vender uma imagem de país "de braços abertos" não parece ser adequada se ainda é a Polícia Federal que recebe os refugiados nos aeroportos; ou se mesmo diante de um discurso "protecionista e integrador", o Estado, na prática, atribui a responsabilidade de acolher os refugiados para as organizações não governamentais e instituições sociais, que muitas vezes não possuem condições financeiras necessárias para todo esse aporte, principalmente em tempos de crises.

Nesse aspecto, lembra Paulo Ricardo Muller, que "a noção de solidariedade está presente no pensamento socioantropológico como indicadora de relações sociais mais ou menos coesas elou politicamente corretas ${ }^{22}$. Com isso, o autor considera que é preciso, em momentos como o que atualmente vivenciamos, compreender que existe uma indissociabilidade entre solidariedade e cooperação, mecanismos que tendem a

${ }^{21}$ Tradução livre de: "Ella está en el horizonte — dice Fernando Birri- Me acerco dos pasos, ella se aleja dos pasos. Camino diez pasos y el horizonte se corre diez pasos más allá. Por mucho que yo camine, nunca la alcanzaré. ¿Para qué sirve la utopía? Para eso sirve: para caminar". (GALEANO, Eduardo. Las Palavras Andantes. 5. ed. Buenos Aires: Catálogos, 2001. p. 230. Disponível na versão online em: <https://vivelatinoamerica.files.wordpress.com/2014/12/gal eano_eduardo-las_palabras_andantes.pdf $>$. Acesso em: 03 Jul 2016)

${ }^{22}$ MULLER, Paulo Ricardo. Noções de Solidariedade e Responsabilidade no Campo da Cooperação Internacional para a proteção de Refugiados. In: Revista Interdisciplinar da Mobilidade Humana, Brasília, Ano XXI, n. 40, p. 229-244, jan./jun. 2013, p. 231. 
ser aplicados por diferentes atores na política de proteção e acolhimento aos refugiados. E, nesse sentido, entende o referido autor que

Não se trata de questionar o quanto a ajuda é movida por interesses instrumentais ou por sentimentos de dever moral, mas sim de explicitar as diferentes lógicas de apropriação, interpretação e ressignificação destas noções postas em prática através do posicionamento dos sujeitos neste circuito. Para tanto é necessário lançarmos um olhar sobre as modalidades de interação entre sujeitos situados em diferentes escalas operacionais e diferentes campos semânticos a partir dos quais interpretam os princípios das políticas de proteção a refugiados, acessando as categorias de entendimento que engendram discursos e práticas agenciadoras das noções de solidariedade e responsabilidade. ${ }^{23}$

Emerge, assim, a urgência de uma sociedade disposta a fazer jus à sua imagem construída internacionalmente. Uma sociedade que atue, com o auxílio do Estado, no combate aos movimentos xenófobos, de forma a evitar o surgimento e crescimento de eventuais grupos ultranacionalistas, como em alguns países da Europa.

A necessidade de superar o "estigma de estrangeiro" na era da informação não é apenas mais uma medida essencial para a inserção e integração dos refugiados no Brasil, senão a mais importante. E mais: é uma postura primordial para a prevalência e efetivação dos direitos humanos na sociedade. $\mathrm{O}$ respeito à diversidade é o caminho chave para que o refugiado se sinta acolhido na sociedade e possa, futuramente, retribuir esse gesto solidário.

$\mathrm{Na}$ senda da sociedade informacional e das questões humanitárias, é preciso lembrar sempre: o estrangeiro, seja ele um imigrante ou um refugiado; seja ele negro, branco, amarelo; seja ele rico, pobre, alfabetizado ou não; seja como for, é um ser humano e como tal merece o trato digno e respeitoso e, sobretudo, o reconhecimento dos seus direitos.

${ }^{23}$ MULLER, Paulo Ricardo. Noções de Solidariedade e Responsabilidade no Campo da Cooperação Internacional para a proteção de Refugiados. In: Revista Interdisciplinar da Mobilidade Humana, Brasília, Ano XXI, n. 40, p. 229-244, jan./jun. 2013,, p. 234-235. 


\section{CONSIDERAÇÕES FINAIS}

Ainda que a comunidade global, integrada pela tecnologia da informação, esteja fragilizada com as constantes guerras e demais catástrofes que nortearam, e cotidianamente norteiam este século XXI, há de se buscar incentivar, promover e preservar o sentimento que de compreensão e acolhimento. Nada e nem ninguém está imune às aventuras da vida, uma vez que, como já dizia o consagrado escritor Machado de Assis, "o destino, como os dramaturgos, não anuncia as peripécias nem o desfecho. Propagar o ódio hoje, e negar sua própria identidade brasileira miscigenada, é certamente esperar para colher mais incertezas do amanhä"24.

A sociedade brasileira ainda caminha a passos miúdos diante da velocidade da sociedade da informação, e o ordenamento jurídico vem seguindo o mesmo rumo. Por esta razão, diante de uma crise humanitária de tamanhas proporções, o que se espera de uma sociedade, cuja formação remonta a junção de diversas etnias, é mais do que acolher os refugiados: é reconhecer nessas pessoas a própria origem do povo brasileiro, atribuindo à informação uma função de verdadeira ferramenta difusora dessa ideia.

Em que pese o Estado, espera-se que este incentive o respeito mútuo e o reconhecimento da pessoa no que toca a sua intrínseca qualidade de ser humano, tutelando o indivíduo das agressões à sua identidade, utilizando-se de políticas públicas de combate aos discursos discriminatórios, não se resumindo apenas a elaborações de leis, mas também fazendo-se mostrar prestando a tutela jurisdicional através de um tratamento adequado à Constituição, atribuindo ao Direito a função de um instrumento que se proponha a "trabalhar para além do próprio texto", buscando a verdadeira essência da isonomia consagrada na Carta Magna para a construção de uma sociedade livre, justa e solidária que vise à promoção do bem de todos, sem qualquer tipo de preconceito e formas de discriminação.

Não se trata, pois, apenas de objetivos e direitos esculpidos, mas transcende um sentimento humanitário que precisa ser, o quanto antes, difundido nessa sociedade informacional, de modo que esta, ao "se colocar no mesmo lugar", consiga, por fim, extirpar o sentimento preconcei-

${ }^{24}$ ASSIS, Machado de. Dom Casmurro. 1. a edição. São Paulo: L\&PM Editores, 1997, v.32, p. 54. 
tuoso que desde os séculos passados tem manchado a história do povo brasileiro.

Nessa senda, é preciso "ver para além das aparências". E mais: é preciso que a informação seja utilizada para difundir esse discurso, e não aqueles que violam os direitos fundamentais. $\mathrm{O}$ mundo precisa de humanidade, e os refugiados precisam de abrigo e proteção.

\section{REFERÊNCIAS BILIOGRÁFICAS}

ABRAÇO CULTURAL. Cursos com refugiados. Disponível em: $<$ http://abracocultural.com.br/>.

ACNUR, Alto Comissariado das Nações Unidas para Refugiados. A situação dos refugiados no mundo: cinquenta anos de ação humanitária. Portugal: A Triunfadora. 2000. Disponível em: < http://www.cidadevirtual.pt/acnur/sowr2000/index.html>. Acesso em: 10 nov. 2015.

. Coleção de Instrumentos de Proteção Nacional e Internacional de Refugiados e Apátridas. Disponível em: <http://www.acnur.o rg/t3/fileadmin/Documentos/portugues/Publicacoes/2012/Lei_947_ 97_e_Coletanea_de_Instrumentos_de_Protecao_Internacional_de_ Refugiados_e_Apatridas.pdf?view=1>. Acesso em: 25 out. 2015. Dados sobre refúgio no Brasil: uma análise estatística (20102014). 2015. Disponível em: < http://www.acnur.o rg/t3/portugues/recursos/estatisticas/>. Acesso em: 22 out. 2015

. Manual de procedimentos e critérios a aplicar para determinar o Estatuto de Refugiado. Genebra: ACNUR, 2011. Disponível em: < http://www.acnur.org/t3/fileadmin/scripts/doc.php ?file=t3/fileadmin/Documentos/portugues/Publicacoes/2013/Manu al_de_procedimentos_e_criterios_para_a_determinacao_da_condic ao_de_refugiado>. Acesso em: 22 out. 2015. (a)

O ACNUR no Brasil. Disponível em: $<$ http://www.acnur.org/t3/portugues/informacao-geral/o-acnur-nobrasil/>. Acesso em: 20 out. 2015.

Sistema de Refúgio Brasileiro: Desafios e perspectivas. Disponível em: <http://www.acnur.org/t3/fileadmin/scripts/doc .php?file=t3/fileadmin/Documentos/portugues/Estatisticas/Sistema 
_de_Refugio_brasileiro_-_Refugio_em_numeros_-_05_05_2016>. Acesso em: 14 mai. 2016.

60 anos de ACNUR: perspectivas de futuro. André de Carvalho Ramos, Gilberto Rodrigues e Guilherme Assis de Almeida, (orgs.). São Paulo: Editora CL-A Cultural, 2011. (b)

ADUS, Instituto de Reintegração do Refugiado no Brasil. Refugiados no

Brasil. Disponível em: <http://www.adus.org.br/refugiados-nobrasil/>. Acesso em: 20 out. 2015.

ASSIS, Machado de. Dom Casmurro. 1. a edição. São Paulo: L\&PM Editores, 1997, [L\&PM POCKET, V.32], p. 54.

BARRETO, Luiz Paulo Teles Ferreira. Refúgio no Brasil: a proteção brasileira aos refugiados e seu impacto nas Américas. 1. ed. Brasília: ACNUR, Ministério da Justiça, 2010.

BRASIL. Lei $n^{\circ}$ 9.474, de 22 de julho de 1997. Define mecanismos para a implementação do Estatuto dos Refugiados de 1951, e determina outras providências.

Constituição Federal da República Federativa do Brasil de 1988. Disponível em www.planalto.gov.br/constituição Acesso em 21/05/2017.

CALDAS, Graça. Mídia, escola e leitura crítica do mundo. Educ. Soc. Campinas, vol. 27, n. 94, p.117-130, jan./abr. 2006. Disponível em <http://www.scielo.br/pdf/es/v27n94/a06v27n94.pdf >. Acesso em: 01 Jul 2016.

CARITAS BRASILEIRA. Disponível em: <http://caritas.org.br/>.

CRANTSCHANINOV, Tamara Ilinsky. Direitos Humanos para refugiados: evolução do tratamento no Brasil. Universidade de São Paulo. São Paulo, 2010. Disponível em: $<$ http://www.academia.edu/406571/Direitos_Humanos_para_refugi ados_evolu\%C3\%A7\%C3\%A3o_do_tratamento_no_Brasil >. Acesso em: 05 nov. 2015.

DUDH, Declaração Universal dos Direitos Humanos. UNIC/Rio. Janeiro, 2009. Disponível em: <http://www.dudh.org.br/wpcontent/uploads/2014/12/dudh.pdf>. Acesso em: 20 out. 2015.

FANTAZZINI, Orlando. Uma agenda proativa para as migrações internacionais. In: ACNUR. Políticas Públicas para as migrações internacionais: migrantes e refugiados. Brasília: Alliance Indústria Gráfica, 2005, p. 11-12.

GALEANO, Eduardo. Las Palavras Andantes. 5. ed. Buenos Aires: Catálogos, 2001. p. 230. Disponível na versão online em: 
https://vivelatinoamerica.files.wordpress.com/2014/12/galeano_ed uardo-las_palabras_andantes.pdf. Acesso em: 03 Jul 2016

GOFFMAN, Erving. Estigma: la identidad deteriorada. 5. ed. Buenos Aires: Amorrortu Editores, 1993, 172p. In: Zélia Maria de Melo. Os estigmas: a deterioração da identidade social. Disponível para consulta online em: $<$ http://proex.pucminas.br/sociedadeinclusiva/anaispdf/estigmas.pd f>. Acesso em: 30 Maio 2016.

HOBSBAWM, Eric. Era dos extremos: o breve século XX (19141991). 2. ed. Tradução: Marcos Santarrita. São Paulo: Companhia das Letras, 1995.

IKMR, I Know My Rights - "Eu conheço meus direitos". Disponível em: <http://www.ikmr.org.br/>. Acesso em: 18 out. 2015.

Declaração de Princípios do Mercosul sobre Proteção Internacional dos Refugiados. Disponível em: $<$ http://www.ikmr.org.br/declaracao-de-principios-do-mercosulsobre-protecao-internacional-dos-refugiados/>. Acesso em: 23 out. 2015.

JUBILUT, Liliana Lyra. O Direito Internacional dos Refugiados e sua Aplicação no Ordenamento Jurídico Brasileiro. São Paulo: ACNUR \& Editora Método, 2007.

LAMAS, Bárbara Gomes. Tropas brasileiras no Haiti. Conjuntura Internacional. 2004. Disponível em: < http://www.pucminas.br/imagedb/conjuntura/CNO_ARQ_NOTIC2 0050802165650.pdf?PHPSESSID=6f637a02ea0df6ebea8ae3824c4 9cba6>.

MENDES, Gilmar Ferreira; COELHO, Inocêncio Mártires; BRANCO, Paulo Gustavo Gonet. Curso de Direito Constitucional. São Paulo: Saraiva, 2009.

MOREIRA, Julia Bertino. O acolhimento dos refugiados no Brasil: políticas, frentes de atuação e atores envolvidos. 2007. Disponível em:

http://www.abep.nepo.unicamp.br/docs/anais/outros/5EncNacSobr eMigracao/comunic_sec_2_aco_ref_bra.pdf>. Acesso em: 10 nov. 2015.

A Problemática dos Refugiados no Mundo: Evolução do Pós-Guerra aos dias atuais. Campinas, 2006. Disponível em: < http://www.abep.nepo.unicamp.br/encontro2006/docspdf/ABEP20 06_909.pdf>. Acesso em: 27 out. 2015. 
MULLER, Paulo Ricardo. Noções de Solidariedade e Responsabilidade no Campo da Cooperação Internacional para a proteção de Refugiados. In: Revista Interdisciplinar da Mobilidade Humana, Brasília, Ano XXI, n. 40, p. 229-244, jan./jun. 2013.

OLIVEIRA, Lucia Lippi. O Brasil dos imigrantes. 2. ed. Rio de Janeiro: Jorge Zahar Ed., 2002.

OLIVEN, Ruben George. Cultura brasileira e Identidade nacional: $o$ eterno retorno. Disponível em: $<$ http://www.anpocs.org/portal/index.php?option=com_docman\&ta sk=doc_view\&gid=654\&Itemid=305>. Acesso em: 21 nov. 2015.

ONU, Organização das Nações Unidas. Disponível em: $<$ http://nacoesunidas.org/>.

PACÍFICO, Andrea Maria Calazans Pacheco. O capital social dos refugiados: bagagem cultural versus políticas públicas. Disponível em:

http://www.academia.edu/689425/O_Capital_Social_dos_Refugiad os_Bagagem_Cultural_e_Pol\%C3\%ADticas_P\%C3\%BAblicas>. Acesso em: 11 nov. 2015.

PAIVA, Odair da Cruz. Intolerância e exclusão: refugiados e deslocados de guerra em São Paulo: 1947-1951. Disponível em: $<$

http://www.anpuhsp.org.br/sp/downloads/CD\%20XVII/ST\%20XX V\%20-\%20II/Odair\%20da\%20Cruz\%20Paiva.pdf>. Acesso em: 29 nov. 2015.

. Histórias da (I)migração: imigrantes e migrantes em São Paulo entre o final do século XIX e o início do século XXI. São Paulo: Arquivo Público do Estado, 2013.

PANIKKAR, Raimundo. Seria a noção de direitos humanos um conceito ocidental? In: Diógenes, $\mathrm{n}^{\circ}$ 5. Brasília: Universidade de Brasília, 1983.

PORTELA, Paulo Henrique Gonçalves. Direito Internacional público e privado. Incluindo noções de Direitos Humanos e de Direito Comunitário. 7. ed. Salvador (BA): JusPodivm, 2015. 1060 p.

SANTAELLA, L. Produção de linguagem e ideologia. São Paulo: Cortez, 1996. In: CALDAS, Graça. Mídia, escola e leitura crítica do mundo. Educ. Soc. Campinas, vol. 27, n. 94, p.117-130, jan./abr. 2006. <http://www.scielo.br/pdf/es/v27n94/a06v27n94.pdf >. Acesso em: $04 \mathrm{Jul} 2016$. 
SOUZA, Júlio César Pinto de. Leitura psicossocial da inserção dos refugiados colombianos em Manaus. Dissertação (Mestrado em Psicologia: Processos Psicossociais). Universidade Federal do Amazonas, 2015. Disponível em: $<$ http://tede.ufam.edu.br/bitstream/tede/4605/2/Disserta\%C3\%A7 $\% \mathrm{C} 3 \% \mathrm{~A} 3 \mathrm{o} \% 20$

J\%C3\%BAlio\%20C\%C3\%A9sar\%20Pinto\%20de\%20Souza.pdf $>$.

THOMPSON, Marcelo. Marco civil ou demarcação de direitos? Democracia, razoabilidade e as fendas na internet do Brasil. RDA - Revista de Direito Administrativo, Rio de Janeiro, v. 261, p. 203-251, set./dez. 2012. Disponível em: http://ssrn.com/abstract=2101322. Acesso em: 08/06/2014.

WALDRON, Jeremy. Dignity and defamation: the visibility of hate. Harvard Law Review, v. 123, n. 1.596, p. 1.597-1.657, 2010.

ZANONI, Anelise. Um Brasil para refugiados. Revista do Instituto Humanitas Unisinos. Refugiados, uma diáspora em tempos globais. 362. ed. Ano X. IHU ON-LINE, 2011. Disponível em: < http://www.ihuonline.unisinos.br/media/pdf/IHUOnlineEdicao362. pdf>. Acesso em: 17 nov. 2015. 
